\title{
Transcriptome analysis of two buffalograss cultivars
}

\author{
Michael Wachholtz ${ }^{1}$, Tiffany Heng-Moss² ${ }^{2}$ Paul Twigg ${ }^{4}$, Lisa Baird ${ }^{5}$, Guoqing Lu ${ }^{1}$ and Keenan Amundsen ${ }^{3 *}$
}

\begin{abstract}
Background: Buffalograss [Buchloë dactyloides (Nutt.) Engel. syn. Bouteloua dactyloides (Nutt.) Columbus] is a United States native turfgrass species that requires less irrigation, fungicides and pesticides compared to more commonly used turfgrass species. In areas where water is limited, interest in this grass species for lawns is increasing. While several buffalograss cultivars have been developed through buffalograss breeding, the timeframe for new cultivar development is long and is limited by a lack of useful genetic resources. Two high throughput next-generation sequencing techniques were used to increase the genomic resources available for buffalograss.

Results: Total RNA was extracted and purified from leaf samples of two buffalograss cultivars. '378' and 'Prestige' cDNA libraries were subjected to high throughput sequencing on the Illumina GA and Roche 454 Titanium FLX sequencing platforms. The 454 platform (3 samples) produced 1,300,885 reads and the Illumina platform (12 samples) generated approximately 332 million reads. The multiple k-mer technique for de novo assembly using Velvet and Oases was applied. A total of 121,288 contigs were assembled that were similar to previously reported Ensembl commelinid sequences. Original Illumina reads were also mapped to the high quality assembly to estimate expression levels of buffalograss transcripts. There were a total of 325 differentially expressed genes between the two buffalograss cultivars. A glycosyl transferase, serine threonine kinase, and nb-arc domain containing transcripts were among those differentially expressed between the two cultivars. These genes have been previously implicated in defense response pathways and may in part explain some of the performance differences between 'Prestige' and ' 378 '.

Conclusions: To date, this is the first high throughput sequencing experiment conducted on buffalograss. In total, 121,288 high quality transcripts were assembled, significantly expanding the limited genetic resources available for buffalograss genetic studies. Additionally, 325 differentially expressed sequences were identified which may contribute to performance or morphological differences between 'Prestige' and '378' buffalograss cultivars.
\end{abstract}

Keywords: Buffalograss, Transcriptome, Next-generation sequencing

\section{Background}

Buffalograss [Buchloë dactyloides (Nutt.) Engel. syn. Bouteloua dactyloides (Nutt.) Columbus] is a turfgrass species native to the Great Plains region of the United States with exceptional drought, cold and heat tolerance. Buffalograss is often considered an ideal low input turfgrass species because it requires relatively less irrigation, fertility, and pesticide inputs to maintain an acceptable level of turfgrass quality compared to more commonly used turfgrass species [1]. With the increased frequency

\footnotetext{
*Correspondence: kamundsen2@unl.edu

${ }^{3}$ Department of Agronomy \& Horticulture, University of Nebraska at Lincoln, Lincoln, NE 68583, USA

Full list of author information is available at the end of the article
}

and duration of drought over the past few growing seasons, buffalograss demand by consumers is on the rise.

Buffalograss has a base haploid chromosome number of 10 and exists as a ploidy series ranging from diploid $(2 \mathrm{n}=$ $20)$ to hexaploid $(2 n=60)$. Diploids and tetraploids appear to be more southerly adapted, while hexaploids are found throughout the northern range of the Great Plains [2]. Buffalograss is a perennial species that is highly stoloniferous, forms a dense sod, has fine leaf texture, and is greyish green in color [1]. Buffalograss is also dioecious and thus is an obligate outcrossing, highly heterogeneous species which complicates cultivar development and genomic studies. Some challenges associated with buffalograss management are its intolerance of shade [3], short growing season in

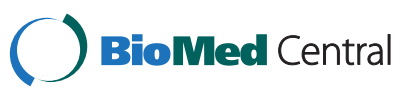


cooler climates [3], and susceptibility to certain pests $[4,5]$. Each of these traits is being addressed through breeding efforts to reduce the impact of these stresses on future buffalograss cultivars. Traditional buffalograss breeding strategies rely on genetic diversity among germplasm and the introgression of positive traits from one cultivar into another with improved turfgrass performance. The development of new buffalograss cultivars is a lengthy process that could be accelerated through the use of expanded genomic resources and molecular assisted breeding strategies.

Relative to the major agronomic food crops, there are few genomic resources available for studying buffalograss; for example, there are no buffalograss EST sequences published in GenBank [6] (accessed on 8/28/2013). To date, most of the genetic studies in buffalograss have been directed towards genetic marker development, resolving the taxonomy of buffalograss, and assessing genetic diversity of individuals among germplasm collections. For example, RAPD and isozyme markers were used to evaluate genetic relationships among two diploid buffalograss populations originating from central Mexico and two originating from Texas [7]. Sequence-related amplified polymorphic markers (SCAR) were used to assess genetic diversity among naturally occurring stands of buffalograss [8]. Both of these genetic marker studies observed a significant amount of genetic diversity among accessions collected from different geographic regions. The matK, $r b c L$, and $c o b$ genes were sequenced from 20 buffalograss accessions along with zoysiagrass (Zoysia japonica Steud.), bermudagrass [Cynodon dactylon (L.) Pers.], and blue grama [Bouteloua gracilis (H.B.K.) Lag. Ex Steud.] accessions [9]. The mitochondrial cob gene showed close association of the buffalograss cultivars 'Bowie' and 'Density' to the blue grama entry, while the plastid genes $m a t K$ and $r b c L$ clearly showed the buffalograss accessions were distinct from the other species studied.

Transcriptome sequence data of non-model organisms, such as buffalograss, is increasingly more accessible through the use of next generation sequencing strategies. Transcriptome sequencing is an ideal way of identifying trait specific genes, efficiently developing genetic markers, characterizing gene expression, and resolving gene networks, and is routinely applied to the study of organisms with little prior genomic information [10]. Next generation sequencing technologies are only just beginning to be applied to the study of turfgrass systems and have thus far focused primarily on improving our understanding of how turfgrasses responds to biotic and abiotic stress. For example, RNA-seq strategies were used to study the interaction between Sclerotinia homoeocarpa, the pathogen causing dollar spot disease, and creeping bentgrass (Agrostis stolonifera L.) whereby several genes were identified from either the host or the pathogen that were differentially expressed during infection [11]. Similarly, the
S. homoeocarpa and creeping bentgrass disease interaction was studied using RNA-seq and transcriptome changes were identified [12]. A better understanding of genes involved in the pathogen-host interactions would facilitate the development of host resistance in future cultivars and help direct cultural practices to reduce the impact of disease. The SOLiD-SAGE technology was used to identify transcriptional changes in a red fescue (Festuca rubra) host infected with the Epichloë festucae endophyte [13]. Endophyte infection is often associated with improved stress tolerance of the host, and this study observed changes in host gene expression resulting from the presence of the endophyte. To the best of our knowledge, to date there have been no high-throughput sequencing experiments done on buffalograss; contributing to the limited genetic information available for studying this species.

In the present study, the transcriptome was sequenced of two buffalograss cultivars, 'Prestige' and '378', known to differ in chinch bug resistance, ploidy level, and other turfgrass performance traits. The cDNA libraries were sequenced with both the Illumina GA and 454 Titanium FLX sequencing platforms, expanding buffalograss genetic resources. This is a valuable resource that turfgrass breeders and others in the turfgrass research community can use as a reference for comparative transcriptome studies, as a platform for genetic marker development, to characterize buffalograss variety differences, and to implement marker assisted breeding strategies for future cultivar development.

\section{Results}

In total, $1,300,885$ sequencing reads were generated on the 454 Titanium FLX sequencer, with 906,812 derived from 'Prestige' and the remaining 394,073 from '378'. The 454 sequencing reads had an average read length of $281 \mathrm{bp}$ with a maximum read length of $669 \mathrm{bp}$. More than $159.3 \mathrm{M}$ and $172.8 \mathrm{M}$ Illumina GA $55 \mathrm{bp}$ sequencing reads were generated for 'Prestige' and '378, respectively. An average of $27.7 \mathrm{M}$ reads was sequenced on the Illumina platform per sample. After strict quality filtering, 73.1 M and 67.6 M reads from 'Prestige' and '378', respectively were used for sequence assembly. For 'Prestige', the combined Velvet/Oases k-mer assemblies with redundant sequences removed generated 265,590 transcripts with an average length of $899 \mathrm{bp}$ and a maximum length of $18,330 \mathrm{bp}$. For ' 378 ', the combined Velvet/ Oases k-mer assemblies generated 241,129 transcripts with an average length of $835 \mathrm{bp}$ and a maximum length of 11,681 bp (Table 1).

Of the 265,590 'Prestige' transcripts, 64,040 had significant BLASTx hits (e-value < 1E-10) to Ensembl commelinid plant protein sequences. Similarly, of the 241,129 '378' transcripts, 57,248 had at least one BLASTx hit. The majority of transcripts had a significant level of sequence identity to 
Table 1 Sequence statistics for transcripts with multiple k-mer assemblies combined and with BLAST matches to Ensembl commelinid reference proteins

\begin{tabular}{|c|c|c|c|c|c|}
\hline Assembly & $\begin{array}{l}\text { No. of } \\
\text { transcripts }\end{array}$ & $\begin{array}{l}\text { Median } \\
\text { (bp) }\end{array}$ & $\begin{array}{l}\text { N50 } \\
\text { (bp) }\end{array}$ & $\begin{array}{l}\text { Mean } \\
\text { (bp) }\end{array}$ & $\begin{array}{l}\text { Longest transcript } \\
\text { (bp) }\end{array}$ \\
\hline Prestige multiple assemblies combined with Oases & 265590 & 678 & 1353 & 899 & 18330 \\
\hline 378 multiple assemblies combined with Oases & 241,129 & 625 & 1253 & 835 & 11681 \\
\hline $\begin{array}{l}\text { Prestige transcripts with BLAST match to Ensembl commelinid } \\
\text { proteins }\end{array}$ & 64,040 & 972 & 1499 & 1145 & 12,236 \\
\hline 378 transcripts with BLAST match to Ensembl commelinid proteins & 57,248 & 919 & 1422 & 1090 & 11,681 \\
\hline
\end{tabular}

foxtail millet (Setaria italica) proteins. The second closest reference species was Sorghum bicolor. A total of 17,512 unigene clusters were created within 'Prestige', and 16,743 clusters within the '378' assembly. The NCBI nonredundant (nr) database lacks foxtail millet proteins, there are only 515 deposited. Sorghum bicolor is the most closely related species in the $\mathrm{nr}$ database based on BLASTp searches (Figure 1).

While an average of 5,603 unigenes between the two transcriptomes only contained one transcript, many unigene clusters contained more than one sequence (Figure 2). These multiple transcript unigene clusters can represent transcription variants, allelic variants, closely related paralogues, misassembled transcripts, or transcripts that were fragmented due to low coverage. The latter case would require scaffolding to resolve based on alignments to reference transcripts, but was not conducted in these assemblies. The unigene containing the most transcripts, 170 transcripts in the ' 378 ' assembly, was similar to the Si027417m.g gene in foxtail millet. This foxtail millet gene also represented the largest unigene cluster in 'Prestige'. NCBI BLAST results indicate that this foxtail millet gene contains an

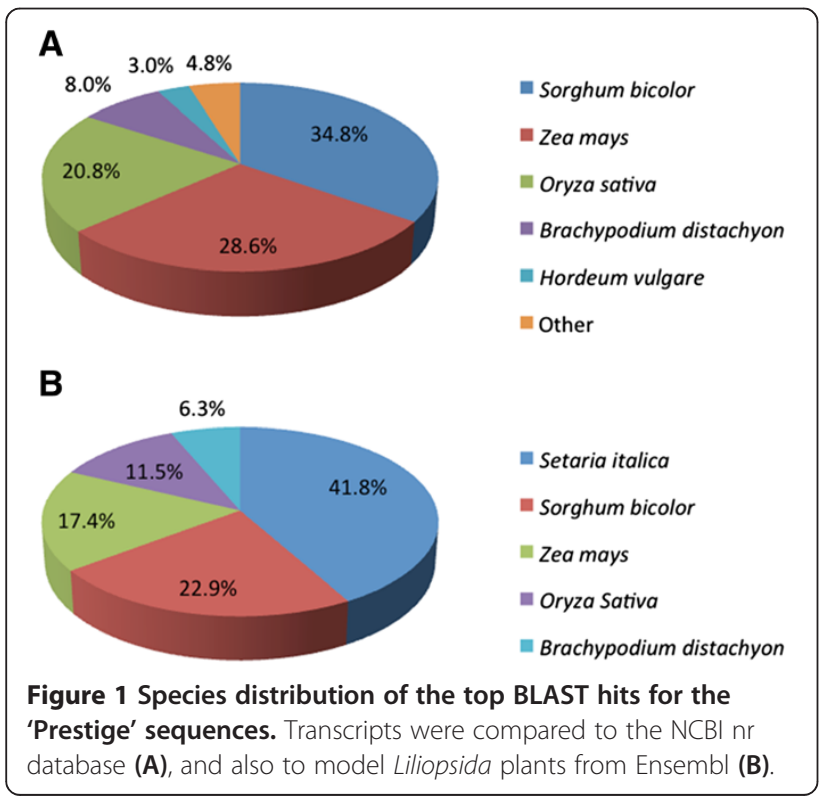

nb-arc domain, which is common in plant disease resistance genes [14].

'Prestige' transcripts shared sequence identity with 15,553 foxtail millet genes, which is $43.8 \%$ of the foxtail millet coding genes [15]. There is a high degree of synteny among the grasses and thus this percentage may be an initial indicator of how much of the buffalograss transcriptome was sequenced. The translated protein sequence of 3,658 transcripts in 'Prestige' and 2,988 transcripts in ' 378 ' aligned to $100 \%$ of a reference protein via BLASTx, indicating that these were complete coding transcripts (Figure 3)

The predicted buffalograss proteins were searched against the NCBI nr database using BLASTp. The resulting BLASTp report was input to the BLAST2GO software. Gene ontology terms were assigned to 58,524 transcripts in 'Prestige' and 52,472 transcripts in ' 378 '. Of these annotated sequences, 17,560 and 15,982 transcripts were assigned Enzyme Codes in 'Prestige' and '378', respectively.

Original Illumina reads, per sample, were aligned to genotype specific assemblies. An average of $19.4 \mathrm{M}$ reads from each sequenced sample successfully aligned to its corresponding transcriptome. Within each sample, an average of $5.5 \mathrm{M}$ of these reads were unique alignments, while an average of $13.9 \mathrm{M}$ mapped reads also aligned to other transcripts.

A reciprocal BLASTp search was performed to identify transcripts shared among the 'Prestige' and '378' translated transcriptome libraries. A total of 19,861 reciprocal hits were identified. Of these reciprocal hits, 6,942 sequences had alignments where 100\% of the 'Prestige' transcript length aligned to the ' 378 ' transcript, or vice versa; these transcripts share the same protein length and sequencing reads covered the entire sequence length.

Using read counts from the previously mentioned Illumina read mapping, expression levels were generated for the transcripts having a reciprocal hit between cultivars. As mentioned in the Methods section, the focus of the gene expression analysis in this study was on transcripts where the majority of reads were uniquely aligned. Using the DESeq Bioconductor package, read 


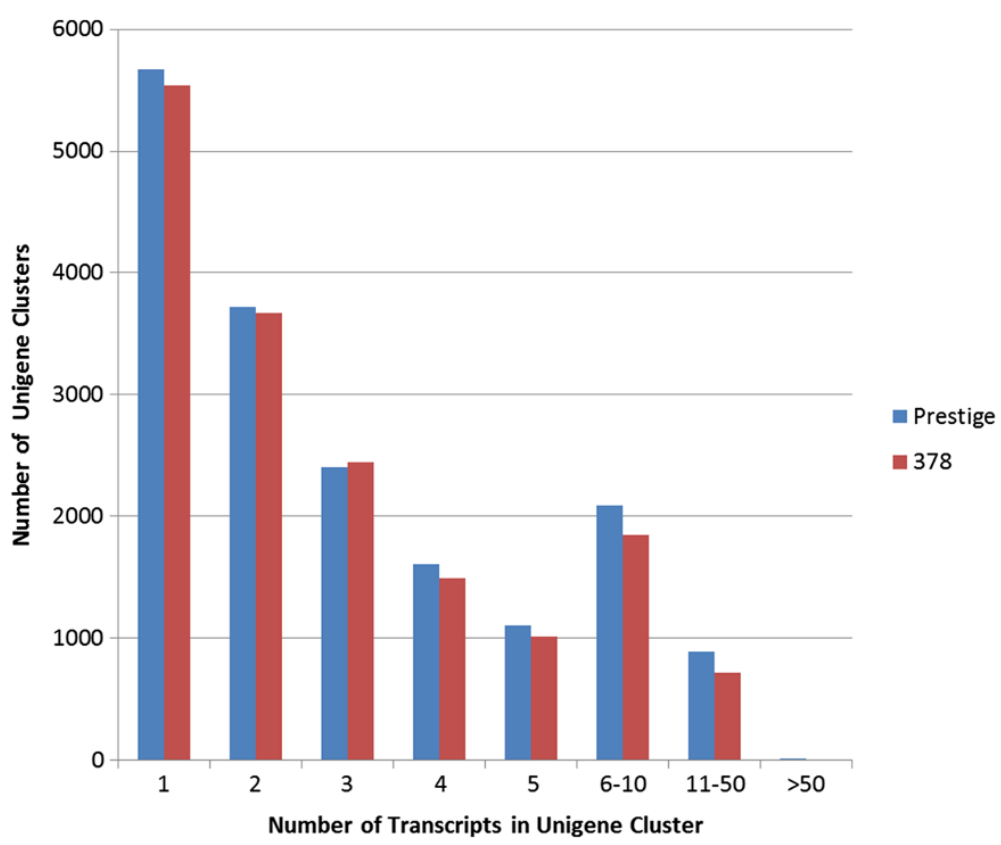

Figure 2 Histogram of Unigene clusters in 'Prestige' and '378' cultivars. X-axis lists how many transcripts are in a unigene, and Y-axis lists how many unigenes are of that size.

counts were normalized using the estimateSizeFactors function, and the expression levels of the selected reciprocal hits were analyzed for statistical significance, $\mathrm{p}$-value $<0.05$ adjusted for multiple testing. There were 325 differentially expressed genes between the two cultivars. Of these genes, 171 had higher expression in 'Prestige', and 154 genes had higher expression in ' 378 '.

Expressed genes in which at least $75 \%$ of the length of the 'Prestige' transcript aligned to at least $75 \%$ of the reciprocal matched ' 378 ' transcript were further analyzed (Figure 4; Table 2). During the process of finding reciprocal sequences among the two genotypes, it was observed that several transcripts had no significant BLAST match to any transcript in the other genotype. This suggests that the gene is not expressed in the other genotype in these samples, it wasn't expressed enough to be assembled, or does not exist in the other genome. Read counts for these transcripts were analyzed, and any sequence where all of its matching reads were unique alignments was considered valid (Table 3).

GO terms were assigned to all 325 differentially expressed genes between the two cultivars, including those having incomplete alignments to a reciprocal sequence. Quantification of Level 3 gene ontology terms was collected for these transcripts (Figure 5).

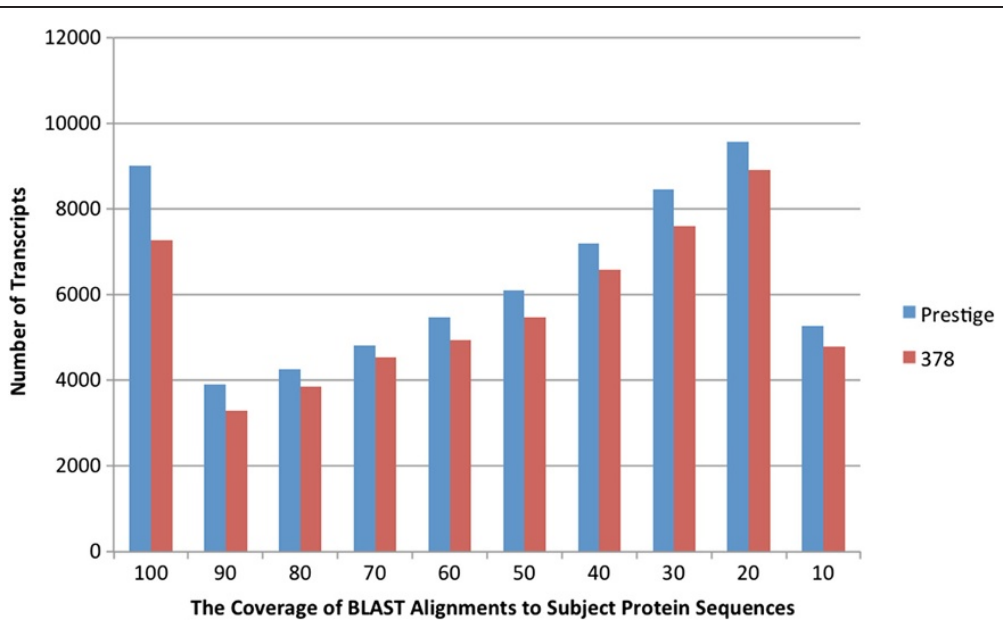

Figure 3 The number of transcripts versus the coverage of blast alignments to subject protein sequences. 


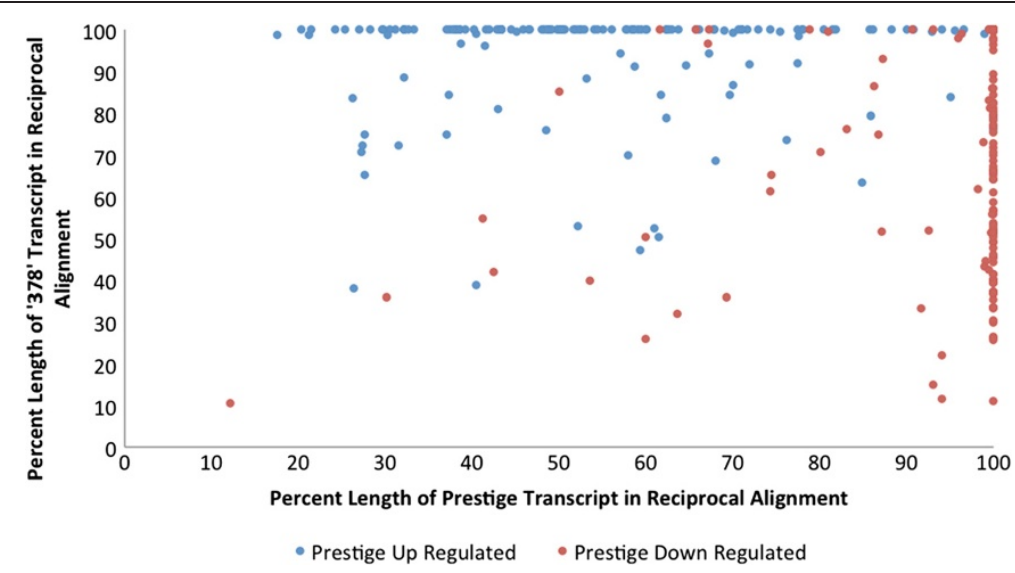

Figure 4 Scatter plot displaying percent length of 'Prestige' transcripts aligning to percent length of ' 378 ' transcripts. Transcripts shown are those that were a reciprocal match and significant expression change was detected.

Gene ontology terms were used to select sequences related to stress and immune response. The parental gene ontology terms for "response to stress" (GO:0006950), "response to other organism" (GO:0051707), and "immune response" (GO:0006955) were found in 27 up-regulated 'Prestige' genes, and in 24 down-regulated 'Prestige' genes. A number of these genes have previous research linking them to defense and immune responses (Table 4).

Table 2 List of significantly expressed genes between Prestige and 378 cultivars

\begin{tabular}{|c|c|c|c|c|c|c|}
\hline $\begin{array}{l}\text { Prestige } \\
\text { transcript }\end{array}$ & $\begin{array}{l}\text { Transcript } \\
\text { length (bp) }\end{array}$ & $\begin{array}{l}\text { Prestige read } \\
\text { numbers }\end{array}$ & $\begin{array}{l}378 \text { read } \\
\text { numbers }\end{array}$ & $\begin{array}{l}\text { Log2 fold } \\
\text { change }\end{array}$ & $\begin{array}{l}\mathrm{P} \text { adjusted value } \\
\text { (multiple testing FDR) }\end{array}$ & Description \\
\hline preC_72587 & 1987 & 2990.6 & 211.6 & -3.82 & $6.79 \mathrm{E}-20$ & $\begin{array}{l}\text { transcription factor-like protein } \\
\text { dpb-like }\end{array}$ \\
\hline preC_221736 & 1868 & 1456.9 & 133.7 & -3.45 & $1.32 \mathrm{E}-13$ & transferring glycosyl \\
\hline preC_91046 & 1253 & 286.7 & 35.0 & -3.04 & 5.40E-08 & $\begin{array}{l}\text { wd repeat-containing protein } \\
\text { 76-like }\end{array}$ \\
\hline preC_256602 & 374 & 29.4 & 3.8 & -2.94 & 2.49E-02 & protein kinase family protein \\
\hline preC_230932 & 507 & 135.8 & 18.5 & -2.88 & 7.85E-03 & $\begin{array}{l}\text { solute carrier family } 25 \text { member } \\
\text { 44-like }\end{array}$ \\
\hline preC_165762 & 589 & 60.9 & 9.4 & -2.69 & $1.17 \mathrm{E}-03$ & transmembrane protein 97 \\
\hline preC_90290 & 713 & 43.1 & 6.8 & -2.67 & $1.98 \mathrm{E}-02$ & $\begin{array}{l}\text { peptidase c } 48 \text { domain family } \\
\text { protein }\end{array}$ \\
\hline preC_211115 & 714 & 386.1 & 61.9 & -2.64 & $3.50 \mathrm{E}-05$ & potassium transporter \\
\hline preC_81161 & 1860 & 1697.7 & 301.4 & -2.49 & $5.86 \mathrm{E}-03$ & $\begin{array}{l}\text { 1-acyl-sn-glycerol-3-phosphate } \\
\text { acyltransferase } 4\end{array}$ \\
\hline preC_261585 & 1410 & 455.2 & 92.2 & -2.30 & $3.51 \mathrm{E}-02$ & ankyrin-like protein \\
\hline preC_231933 & 216 & 64.6 & 275.3 & 2.09 & $1.51 \mathrm{E}-05$ & chalcone isomerase-like protein \\
\hline preC_101008 & 1056 & 153.7 & 673.8 & 2.13 & 3.37E-03 & ras-related protein raba3-like \\
\hline preC_26965 & 294 & 100.4 & 448.7 & 2.16 & $4.51 \mathrm{E}-06$ & tata-binding protein2 \\
\hline preC_127066 & 1068 & 41.4 & 206.6 & 2.32 & 7.43E-03 & dna cross-link repair protein snm 1 \\
\hline preC_134037 & 488 & 15.8 & 120.8 & 2.93 & 4.87E-07 & ent-kaurenoic acid partial \\
\hline preC_41455 & 462 & 15.6 & 119.7 & 2.94 & 3.17E-06 & dna helicase \\
\hline preC_241217 & 352 & 19.7 & 154.3 & 2.97 & $2.86 \mathrm{E}-07$ & $\begin{array}{l}\text { f-box kelch-repeat protein } \\
\text { skip6-like }\end{array}$ \\
\hline preC_217560 & 350 & 8.3 & 68.0 & 3.03 & 2.93E-02 & sister of ramosa partial \\
\hline preC_42285 & 748 & 57.3 & 1020.9 & 4.16 & $2.86 \mathrm{E}-04$ & cationic peroxidase 1-like \\
\hline preC_226473 & 1365 & 173.6 & 4669.0 & 4.75 & 4.77E-25 & $\begin{array}{l}\text { pentatricopeptide repeat- } \\
\text { containing protein }\end{array}$ \\
\hline
\end{tabular}


Table 3 Hypothetical cultivar-specific genes based upon the reciprocal blast

\begin{tabular}{|c|c|c|c|}
\hline Transcript & $\begin{array}{l}\text { Transcript } \\
\text { length (bp) }\end{array}$ & $\begin{array}{l}\text { Average read } \\
\text { numbers }\end{array}$ & Description \\
\hline \multicolumn{4}{|l|}{ Prestige } \\
\hline preC_247169 & 647 & 206.0 & $\begin{array}{l}\text { dna repair and } \\
\text { recombination protein }\end{array}$ \\
\hline preC_214648 & 316 & 61.5 & maize proteinase inhibitor \\
\hline preC_236041 & 545 & 54.0 & copper transporter 1 \\
\hline preC_262069 & 551 & 33.3 & $\begin{array}{l}\text { proteasome assembly } \\
\text { chaperone } 2\end{array}$ \\
\hline preC_256520 & 237 & 28.2 & $\begin{array}{l}\text { e-cadherin binding } \\
\text { protein }\end{array}$ \\
\hline preC_167144 & 650 & 23.7 & cle family 306 protein \\
\hline preC_256357 & 190 & 21.2 & $\begin{array}{l}\text { zinc finger family } \\
\text { expressed }\end{array}$ \\
\hline preC_128843 & 234 & 15.2 & $\begin{array}{l}\text { pentatricopeptide repeat- } \\
\text { containing protein }\end{array}$ \\
\hline preC_231580 & 353 & 14.8 & s-receptor kinase \\
\hline preC_169805 & 381 & 13.5 & $\begin{array}{l}\text { protein epidermal } \\
\text { patterning factor 2-like }\end{array}$ \\
\hline \multicolumn{4}{|l|}{378} \\
\hline 378C_71451 & 258 & 278.7 & snare-like protein \\
\hline 378C_151851 & 237 & 108.5 & $\begin{array}{l}\text { tubulin-specific chaperone } \\
\text { d-like }\end{array}$ \\
\hline 378C_238144 & 303 & 84.2 & subtilisin-like protease \\
\hline 378C_152448 & 174 & 70.7 & lin1 protein \\
\hline 378C_199252 & 175 & 51.8 & $\begin{array}{l}\text { craniofacial development } \\
\text { protein 1-like }\end{array}$ \\
\hline 378C_223520 & 325 & 47.0 & pollen-specific protein like \\
\hline 378C_24916 & 192 & 18.5 & trab domain-containing \\
\hline 378C_235655 & 173 & 16.8 & $\begin{array}{l}\text { nicotinate-nucleotide } \\
\text { pyrophosphorylase }\end{array}$ \\
\hline 378C_202598 & 275 & 15.3 & growth-regulating factor 2 \\
\hline 378C_135613 & 214 & 10.2 & $\begin{array}{l}\text { serine threonine-protein } \\
\text { kinase ctr1-like }\end{array}$ \\
\hline
\end{tabular}

Listed are the top 10 most highly expressed from each cultivar with the removal of sequences of vague descriptions. Average expression is a measure of reads mapped per sample.

\section{Discussion}

There are limited genetic resources available for studying buffalograss, however with current next generation sequencing and de novo assembly strategies, high throughput sequencing can help bridge this buffalograss knowledge gap. In the present study, 121,288 high quality transcripts were reconstituted from 'Prestige' and '378' buffalograss cultivars, utilizing a combination of Illumina GA and Roche 454 Titanium FLX sequencing. Transcripts were found to be differentially expressed between samples of the same genotype collected at different times. Physiological differences are expected to occur between the two sampling times for a given genotype. Since the scope of this research was to expand buffalograss genetic resources and characterize differences between ' 378 ' and 'Prestige', differences occurring within a genotype between the two time points were not examined.

When compared to the NCBI nr database, approximately $50 \%$ of the transcripts had BLASTp hits to Sorghum bicolor proteins, while only $5 \%$ of the transcripts had hits to Brachypodium (Brachypodium distachyon). Brachypodium is often considered a model for the study of grasses, but in this instance was the least informative when compared to the buffalograss transcripts (Figure 1). There are approximately three times as many $S$. bicolor sequences in the $\mathrm{nr}$ database compared to Brachypodium which may help explain why more $S$. bicolor hits were returned. Additionally, both $S$. bicolor and buffalograss are warm season, $\mathrm{C} 4$, grasses while Brachypodium is a cool season, C3, grass and therefore it is not surprising that buffalograss sequences were more similar to S. bicolor.

The two buffalograss genotypes used in this study, 'Prestige' and '378', are known to differ in terms of their resistance to chinch bugs, an important insect pest on buffalograss [36] [37]. Previous data suggests that oxidative enzymes play a role in chinch bug resistance in buffalograss [38]. For example, the chinch bug resistant cultivar 'Prestige' had higher peroxidase activity under both uninfested and chinch bug-infested conditions compared to the susceptible '378' [36]. In the present study, 325 differentially expressed genes between these two genotypes were identified (Table 2). If 'Prestige' is predisposed for chinch bug resistance, genes expressed higher in 'Prestige' compared to susceptible genotypes may be involved in the resistance mechanism. Similarly, genes more highly expressed in the susceptible cultivar may confer susceptibility.

The differences in gene expression between genotypes may account for some of the performance differences among these cultivars. Selecting expressed genes based on gene ontology terms for stress and immune response highlights a potential starting point for understanding these mechanisms. Several of these genes have been researched in regards to stress tolerance. For example, the nb-arc domain-containing and the nbs-lrr class of proteins are known to be involved in a plant's defense response. The nucleotide binding and amino-terminal domains contain a nucleotide-binding site and may act as a molecular switch, regulating specific downstream pathways. Large unigene clusters from both ' 378 ' and 'Prestige' were similar to the nb-arc gene, Si027417m.g, from foxtail millet. The preC_246578 transcript has higher average read counts in 'Prestige' (177.09 average reads) compared to '378' (7.79 average reads), representing a-4.51 $\log 2$ fold difference in expression $(\mathrm{p}$-value $=3.1 \mathrm{E}-02)$ between the two cultivars (Table 4$)$. 


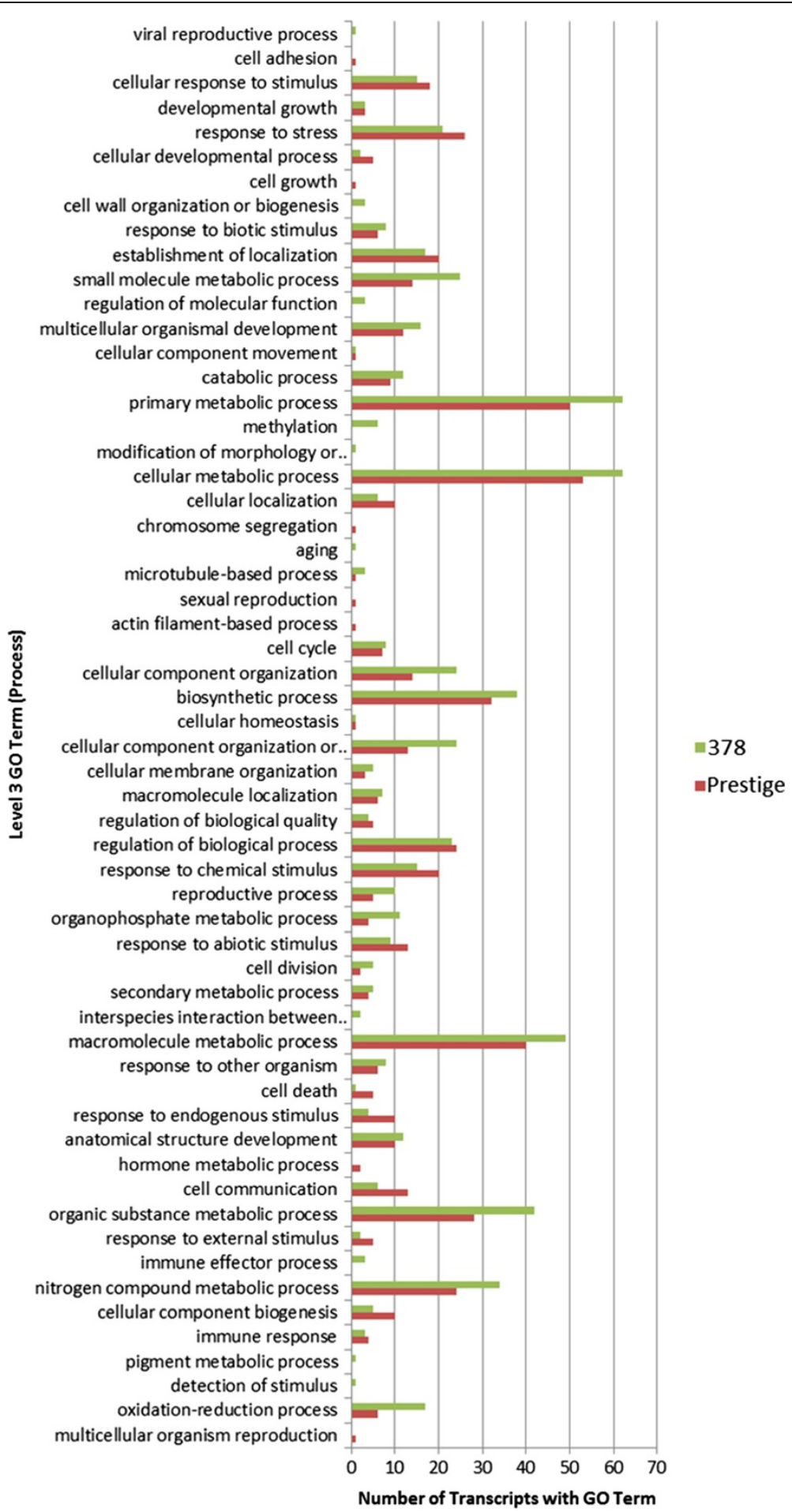

Figure 5 Number of significantly expressed genes in each of the Level $3 \mathrm{GO}$ biological processes. Transcripts with higher expression in 'Prestige' than in '378' are in red. Transcripts with higher expression in '378' than in 'Prestige' are in green.

The transcript, preC_224469, also had higher expression in 'Prestige' than ' 378 ' ( $\log 2$ fold change $=-3.32$; $\mathrm{p}$-value = 8.85e-03). The preC_224469 transcript is predicted to be a member of the nbs-lrr family of genes. The leucine-rich repeat (lrr) domain may act as the signaling molecule and be involved in recognizing early signs of a pathogen attack [16]. The predicted coding sequences from these transcripts contain nb-arc domains. The 
Table 4 Significantly expressed genes that have previous research evidence of stress response

\begin{tabular}{|c|c|c|c|c|c|c|c|}
\hline Prestige transcript & Transcript length (bp) & Prestige read numbers & 378 read numbers & Log2 fold change & p-value & Description & References \\
\hline preC_246578 & 2200 & 177.09 & 7.79 & -4.51 & $3.10 \mathrm{E}-02$ & nb-arc domain-containing protein & [16-18] \\
\hline preC_139482 & 693 & 31.78 & 2.73 & -3.54 & $1.27 \mathrm{E}-03$ & serine threonine kinase (U-box domain) & {$[19-22]$} \\
\hline preC_221736 & 1868 & 1456.86 & 133.67 & -3.45 & $1.32 \mathrm{E}-13$ & transferring glycosyl & {$[23-25]$} \\
\hline preC_224469 & 1554 & 162.26 & 16.25 & -3.32 & 8.85E-03 & nbs-Irr class disease resistance protein & [16-18] \\
\hline preC_86410 & 2051 & 362.42 & 60.17 & -2.59 & 1.15E-05 & dna repair protein xrcc2-like protein & {$[26,27]$} \\
\hline preC_231454 & 1257 & 523.56 & 1972.11 & 1.91 & 2.99E-05 & uracil phosphoribosyltransferase & {$[28]$} \\
\hline preC_143034 & 881 & 111.18 & 449.67 & 2.02 & $2.32 \mathrm{E}-05$ & chloroplast processing peptidase & [29] \\
\hline preC_249539 & 576 & 30.03 & 132.51 & 2.14 & $2.26 \mathrm{E}-04$ & gamma-glutamyl transpeptidase 1 & {$[30-32]$} \\
\hline preC_127066 & 1068 & 41.38 & 206.6 & 2.32 & 7.43E-03 & dna cross-link repair protein snm1 & [33] \\
\hline preC_42285 & 748 & 57.27 & 1020.91 & 4.16 & 2.86E-04 & cationic peroxidase 1-like & {$[34,35]$} \\
\hline
\end{tabular}

Genes containing GO terms "response to stress", "immune response" and "response to other organism" were selected. 
nb-arc containing proteins are most often associated with disease resistance. There has been limited research characterizing differences in disease resistance of 'Prestige' and '378', so it would be interesting to test if 'Prestige' is more resistant to disease relative to '378' and monitor expression of these genes during hostpathogen interactions.

Receptor like kinases also contain an lrr domain and may be involved in early pathogen attack recognition and regulate the level of response to pathogen attack, playing a role in triggering early defense response signaling mechanisms [19]. The transcript, preC_231580, is a serine threonine kinase and had higher expression in 'Prestige' relative to '378' $(\log 2$ fold change $=-3.54$, $\mathrm{p}$-value $=1.27 \mathrm{e}-03$ ).

Glycosyl transferases are also involved in stressinduced plant response and show elevated expression in response to several signaling molecules including hydrogen peroxide [23]. For example, expression of two glycosyltransferases, UGT73B and UGT73B5, were important for Arabidopsis resistance to Pseudomonas [23]. The relative higher expression of a transferring glycosyl, preC_221736 (Table 4), in 'Prestige' compared to '378' ( $\log 2$ fold change $=-3.45$, p-value $=1.32 \mathrm{e}-13)$ is of particular interest since response to oxidative stress may be one mechanism conferring resistance to chinch bugs in 'Prestige' [38].

The majority of the defense response genes identified in this study are not directly linked to insect resistance, however this study characterizes differences between 'Prestige' and '378' which may facilitate a better understanding of host pest interactions in future studies. The majority of the previously mentioned defense response genes are associated with disease resistance. Buffalograss is most commonly grown throughout the Great Plains region of the United States [1] and since buffalograss grows in this relatively arid region of the country, there is less disease pressure than in more humid regions. As a result, limited research has been done to evaluate disease resistance of 'Prestige' and '378'.

Since two distinct buffalograss genotypes were sequenced here, genotypic differences such as single nucleotide polymorphisms, copy numbers of simple sequence repeats, insertion/deletions, and transposable element insertion polymorphisms [39] could be exploited to develop genetic markers for cultivar discrimination or associated with a trait of interest that differs between the two genotypes. In addition, since the sequences presented here are based on expressed transcripts, any genetic markers developed from these sequences are, by nature of the study, gene-based and ultimately more valuable for future molecular-based cultivar development strategies. Since for example, '378' and 'Prestige' are known to differ in chinch bug resistance, the identification of polymorphic homologous sequences in these plants is a first step at developing markers to use in a marker assisted breeding scheme to improve chinch bug resistance. This research would need further investigation to characterize the markers in a broader germplasm base that has been evaluated for chinch bug resistance.

\section{Conclusions}

This is the first report of transcriptome sequencing of Buffalograss [Buchloë dactyloides (Nutt.) Engel. syn. Bouteloua dactyloides (Nutt.) Columbus], the most widely used native turfgrass species in the United States. Transcriptomes of buffalograss cultivars ' 378 ' and 'Prestige' were sequenced by Illumina GA and Roche 454 Titanium FLX sequencing platforms and 121,288 high quality transcripts were assembled. There were 15,553 'Prestige' transcripts that had significant BLAST hits to foxtail millet (Setaria italica) which could be useful for future comparative genetic studies between these species. Transcriptional profiling revealed 325 differentially expressed genes between '378' and 'Prestige' and may in part help explain cultivar differences. At the time of this study, there were no reported buffalograss EST sequences in NCBI and only 34 nucleotide sequences (accessed August 28th, 2013), so this study significantly expands on the limited genetic resources available for studying buffalograss. The data presented here will act as a platform for genetic marker development, a basis for marker assisted breeding strategies, and a reference for future transcript expression studies.

\section{Methods}

\section{Sample preparation and sequencing}

Vegetative plugs $(10.6 \mathrm{~cm}$ diameter $\times 8 \mathrm{~cm}$ deep $)$ of '378' and 'Prestige' were collected from the University of Nebraska Agricultural Research and Development Center, near Mead, NE. Individual stolons from a single plant of each cultivar were planted in SC-10 Super Cell single cell $3.8 \mathrm{~cm}$ diameter $\times 21 \mathrm{~cm}$ deep cone-tainers (Stuewe \& Sons, Inc. Corvallis, OR). The clonal ramets were used for the sequencing studies. The soil mixture was a ratio of 2:1:3:3 sand, soil, peat, and perlite. Buffalograss plants were watered and fertilized (20 N$10 \mathrm{P}-20 \mathrm{~K}$ soluble) as needed. Plants were maintained at a temperature of $24 \pm 3^{\circ} \mathrm{C}$ and a $16 \mathrm{~h}$ photoperiod under 400-watt high-intensity discharge lamps.

The experiment was designed as a $2 \times 2$ factorial with two buffalograss genotypes ('Prestige' and ' 378 ') and two distinct time points seven days apart. The study was arranged as a randomized complete block design with six replications. Buffalograss leaf samples were collected from three replicates of 'Prestige' and three replicates of '378'. A similar set of leaf samples were collected seven days later. For each cultivar, two separate time points were used to minimize transcriptional variation introduced by changes in the environment, growth stage, or 
physiological differences of the plants. Total RNA was isolated from the leaf samples and all 12 were prepared for sequencing on the Illumina GA sequencing platform. A single leaf sample of 'Prestige' and a single leaf sample of ' 378 ' collected on the first sampling date, along with a single sample of 'Prestige' collected on the second sampling date were prepared for sequencing on the Roche 454 Titanium FLX sequencer. Leaf tissue was collected for RNA extraction and immediately frozen in liquid nitrogen and stored at $-80^{\circ} \mathrm{C}$. Four $100 \mathrm{mg}$ leaf tissue samples for each of the 12 buffalograss samples were used as starting material in the RNA extraction procedure and later merged such that there was one composite RNA sample per buffalograss sample. In short, mRNA was then extracted using the FastTrackMAG maxi kit (Invitrogen \#K158002) and cDNA was created using the QuantiTect Whole Transcriptome kit (Qiagen \#207043). The cDNA was cleaned up using the QiAamp DNA Blood mini kit (Qiagen \#51104) before submitting the samples for sequencing.

The leaf tissue mRNA samples were sequenced on the 454 Titanium FLX platform and each sample used one half picotiter plate. A total of twelve samples were sequenced on an Illumina GA Sequencer; these samples consisted of 3 replications of each genotype collected at the first and second time points. One Illumina flowcell lane was used for each sample.

\section{Data filtering and de novo assembly}

A strict quality filtering pipeline was used to select reads for assembly. 454 reads were quality filtered and polyA tail trimmed using Newbler 2.6 software with the "-cdna-tr" options [40]. Redundant reads sharing 100\% identity were removed using CD-HIT-454 [41]. Reads longer than $75 \mathrm{bp}$ were selected as "long" reads for the Velvet/Oases assembly process. These reads were used as reference sequences in the Velvet assembler.

Illumina reads containing at least one base with a quality score below 10 were removed, as well as duplicate reads using FastQ program. PolyA tail trimming was performed by removing reads with at least half of the read length containing all adenines or thymines. Reads containing adapter sequences were identified and removed with Tagdust [42].

Separate transcriptomes were assembled for each genotype. Due to the polyploid nature of these plants and a potential high level of intra-organism and interorganism variation, such as genome rearrangements or paralogue genes unique to one genotype, we decided to not combine genotype reads. Combining reads from both genotypes could potentially complicate the assembly process and create inaccurate transcripts. Assembly was performed using Velvet/Oases software [43]. Multiple assemblies were created per genotype, using odd k-mer values 27-51. Previous studies have shown that using multiple assemblies, at varying k-mer values, captures more lowly expressed transcripts when compared with a single k-mer assembly [44]. Combined transcripts from the multiple k-mer assemblies were run through the CD-HIT-EST program to remove redundant transcripts sharing 100\% identity [41].

\section{Functional annotation}

Transcripts from the two genotype specific assemblies were aligned to a database containing all Ensembl proteins from Brachypodium distachyon, Oryza sativa, Setaria italica, Sorghum bicolor, and Zea mays using BLASTx, e-value threshold of 10e-10. Initial BLASTx results showed that Setaria italica produced the majority of best BLASTx hits, so this reference species was chosen as a beginning reference for annotation. BLASTx was again used to compare assembled transcripts to only Setaria italica proteins. Transcripts were assigned to unigene clusters based on their best gene hit within a reference species. Any transcripts without a BLASTx hit to Setaria italica were compared to a database of Brachypodium distachyon, Oryza sativa, Sorghum bicolor, and Zea mays proteins. These transcripts were also assigned to unigene clusters based on their best BLASTx hit to this secondary reference protein database. The Ensembl gene accession names were used to label the unigene clusters. Any remaining transcripts not having a significant BLASTx hit to Ensembl plant proteins were removed from the transcriptome and not used in downstream analysis.

Using the BLASTx reports from the previous Ensembl protein search, translated open reading frames were extracted from the transcripts using the OrfPredictor software [45]. These extracted protein sequences were input to CD-HIT with $100 \%$ identity threshold to remove transcripts with identical protein translations. The remaining buffalograss protein sequences were compared to the NCBI nr database using BLASTp (e-value threshold of 10E-10). The BLASTp results were input into the BLAST2GO program to assign sequence descriptions, gene ontology terms, and enzyme commission numbers [46].

Extracted ORF sequences from the 'Prestige' assembly were compared to ' 378 ' sequences via BLASTp (e-value 10E-10), and vice versa. If two transcripts from both genotypes had a reciprocal best BLASTp hit to each other, these two transcripts were assigned the same reciprocal hit ID number and considered to be the same gene in the two genotypes. If a reciprocal hit transcript of one genotype only aligns to a portion of the reciprocal hit in the other genotype $(<75 \%$ of the length of either transcript) it was discarded. These shorter alignments can occur because of sequence variation, low expression, and 
incomplete assembly. The $75 \%$ cutoff was chosen to limit the occurrence of false positives and to return longer reciprocal hits which could be useful in future comparative genetic studies between these cultivars.

\section{Expression analysis}

All genotype specific Illumina reads, including reads not used in the assembly process, were aligned to the genotype specific transcriptome using Bowtie alignment software [47]. Read counts for transcripts with a reciprocal match to the other transcriptome were counted and extracted for gene expression analysis, per replicate and time point of sample. Due to the polyploidy of the genomes, and a high number of closely related paralogues within plants, a portion of aligned reads will align to more than one transcript. These "multi-mapped" reads can lead to false read counts for many transcripts. For gene expression analysis, we only examined transcripts with a reciprocal hit in the other genotype where $>75 \%$ of the aligned reads were unique alignments, not aligning to any other transcripts. Per replicate and time point, the sum of uniquely aligned reads was output to a matrix. The two time points were used to minimize transcriptional variation for each genotype introduced by environmental changes at the time the samples were taken and physiological differences. Therefore all six samples within a genotype were treated as replicates for the statistical analysis. Relative expression based on read counts was used instead of RPKM values because the transcriptomes varied by sequence number and sequence lengths. The matrix of read counts was input into DESeq R Statistical package to identify transcripts with significant expression between genotypes (FDR < 0.05) [48]. The read counts of transcripts having no significant BLAST hit to the other genotype were also examined, as these may represent transcripts not assembled or expressed in the other transcriptome. Differentially expressed sequences were examined via BLAST and the NCBI nr database to determine if they are plant proteins or results of metatranscriptome contamination (e.g. bacteria or fungi).

\section{Availability of supporting data}

The data sets supporting the results of this article are available in the BioProject (BioProject:PRJNA207980) repository of the National Center for Biotechnology Information, http://www.ncbi.nlm.nih.gov/bioproject/? term=PRJNA207980.

\section{Competing interests}

The authors declare that they have no competing interests.

\section{Authors' contributions}

The project was conceived by THM and PT. MW conducted de novo transcriptome assembly and transcriptional profiling. MW, KLA and GL oversaw bioinformatics analyses. LB, THM, PT, and KLA interpreted biological relevance of results. MW and KLA wrote the manuscript and all authors read, edited, and approved the manuscript.

\section{Acknowledgements}

We thank the University of Nebraska-Lincoln (UNL) Core for applied Genomics and Ecology facility for the 454 GS-FLX sequencing and the UNL Biotechnology Center for Illumina GAll sequencing. This research was funded by research grants from the Nebraska Research Initiative and the United States Golf Association and we thank them for their support and generosity.

\section{Author details}

'Department of Biology and School of Interdisciplinary Informatics, University of Nebraska at Omaha, Omaha, NE 68182, USA. ²Department of Entomology, University of Nebraska at Lincoln, Lincoln, NE 68583, USA. ${ }^{3}$ Department of Agronomy \& Horticulture, University of Nebraska at Lincoln, Lincoln, NE 68583, USA. ${ }^{4}$ Department of Biology, University of Nebraska at Kearney, Kearney, NE 68849, USA. ${ }^{5}$ Department of Biology, University of San Diego, San Diego, CA 92110, USA.

Received: 19 June 2013 Accepted: 9 September 2013

Published: 11 September 2013

\section{References}

1. Shearman RC, Riordan TP, Johnson PG: Buffalograss. In Warm-season (C4) grasses, agronomy monograph 45. Edited by Moser LE, Burson BL, Sollenberger LE. Madison: American Society of Agronomy, Crop Science Society of America, Soil Science Society of America; 2004:1003-1026

2. Johnson PG, Riordan TP, Arumuganathan K: Ploidy level determinations in buffalograss clones and populations. Crop Sci 1998, 38(2):478-482.

3. Wu L, Harivandi A: Buffalograss response to cold, shade, and salinity. Calif Turfgrass Cult 1995, 45(1/2):5-7.

4. Baxendale FP, Heng-Moss TM, Riordan TP: Blissus occiduus barber (Hemiptera: Lygaeidae): a chinch bug pest new to buffalograss turf. J Econ Entomol 1999, 92(5):1172-1176.

5. Wenger L: Buffalograss, bulletin 321. Manhattan: Kansas Agricultural Experiment Station; 1943

6. Benson DA, Karsch-Mizrachi I, Lipman DJ, Ostell J, Sayers EW: GenBank. Nucleic Acids Res 2012, 40(D1):D48-D53.

7. Peakall R, Smouse PE, Huff DR: Evolutionary implications of allozyme and RAPD variation in diploid populations of dioecious buffalograss Buchloe dactyloides. Mol Ecol 1995, 4(2):135-147.

8. Gulsen O, Shearman RC, Vogel KP, Lee DJ, Baenziger PS, Heng-Moss TM, Budak H: Nuclear genome diversity and relationships among naturally occurring buffalograss genotypes determined by sequence-related amplified polymorphism markers. HortSci 2005, 40(3):537-541.

9. Budak H, Shearman RC, Dweikat I: Evolution of Buchloe dactyloides based on cloning and sequencing of matK, rbcL, and cob genes from plastid and mitochondrial genomes. Genome 2005, 48(3):411-416.

10. Wang Z, Gerstein M, Snyder M: RNA-Seq: a revolutionary tool for transcriptomics. Nat Rev Genet 2009, 10(1):57-63.

11. Orshinsky AM, Hu J, Opiyo SO, Reddyvari-Channarayappa V, Mitchell TK, et al: RNA-Seq analysis of the sclerotinia homoeocarpa-creeping bentgrass pathosystem. PLOS ONE 2012, 7(8). doi:10.1371/journal. pone.0041150.

12. Venu RC, Zhang Y, Weaver B, Carswell P, Mitchell TK, Meyers BC, Boehm MJ, Wang G: Large scale identification of genes involved in plant-fungal interactions using Illumina's sequencing-by-synthesis technology. Fungal Genomics Methods and Protoc, Methods in Mol Biol 2001, 722:167-178.

13. Ambrose KV, Belanger FC: SOLiD-SAGE of endophyte-infected red fescue reveals numerous effects on host transcriptome and an abundance of highly expressed fungal secreted proteins. PLOS ONE 2012, 7(12):E53214. doi:10.1371/journal.pone.0053214

14. Van Der Biezen EA, Jones JD: The NB-ARC domain: a novel signalling motif shared by plant resistance gene products and regulators of cell death in animals. Curr Biol 1998, 8(7):226-227.

15. Bennetzen JL, Schmutz J, Wang H, Percifield R, Hawkins J, Pontaroli AC, Estep M, Feng L, Vaughn JN, Grimwood J, Jenkins J, Barry K, Lindquist E, Hellsten U, Deshpande S, Wang X, Wu X, Mitros T, Triplett J, Yang X, Ye C, Mauro-Herrera M, Wang L, Li P, Sharma M, Sharma R, Ronald PC, Panaud O, Kellogg EA, Brutnell TP, Doust AN, Tuskan GA, Rokhsar D, Devos KM, et al: 
Reference genome sequence of the model plant Seteria. Nat Biotechnol 2012, 30:555-561.

16. Takken FL, Albrecht M, Tameling Wl: Resistance proteins: molecular switches of plant defence. Curr Opin Plant Biol 2006, 9(4):383-390.

17. Van Ooijen G, Mayr G, Kasiem MM, Albrecht M, Cornelissen BJ, Takken FL: Structure-function analysis of the NB-ARC domain of plant disease resistance proteins. J Exp Bot 2008, 59(6):1383-1397.

18. DeYoung BJ, Innes RW: Plant NBS-LRR proteins in pathogen sensing and host defense. Nat Immunol 2006, 7(12):1243-1249.

19. Afzal AJ, Wood AJ, Lightfoot DA: Plant receptor-like serine threonine kinases: roles in signaling and plant defense. Mol Plant Microbe Interact 2008, 21(5):507-517.

20. Yoshida S, Parniske M: Regulation of plant symbiosis receptor kinase through serine and threonine phosphorylation. J Biol Chem 2005, 280(10):9203-9209.

21. Goff KE, Ramonell KM: The role and regulation of receptor-like kinases in plant defense. Gene Regul Syst Bio 2007, 1:167-175.

22. Yee D, Goring DR: The diversity of plant U-box E3 ubiquitin ligases: from upstream activators to downstream target substrates. J Exp Bot 2009, 60(4):1109-1121

23. Langlois-Meurinne M, Gachon CMM, Saindrenan P: Pathogen-responsive expression of glycosyltransferase genes UGT73B3 and UGT73B5 is necessary for resistance to pseudomonas syringae pv tomato in Arabidopsis. Plant Physiol 2005, 139(4):1890-1901.

24. Vogt $T$, Jones P: Glycosyltransferases in plant natural product synthesis: characterization of a supergene family. Trends Plant Sci 2000, 5(9):380-386.

25. Queval G, Issakidis-Bourquet E, Hoeberichts FA, Vandorpe M, Gakiere B, Vanacker H, Miginiac-Maslow M, Van Breusegem F, Noctor G: Conditional oxidative stress responses in the Arabidopsis photorespiratory mutant cat2 demonstrate that redox state is a key modulator of daylength-dependent gene expression, and define photoperiod as a crucial factor in the regulation of $\mathrm{H}_{2} \mathrm{O} 2$-induced cell death. Plant J 2007, 52(4):640-657.

26. Ishikawa K, Ogawa T, Hirosue E, Nakayama Y, Harada K, Fukusaki E, Yoshimura K, Shigeoka S: Modulation of the poly(ADP-ribosyl)ation reaction via the Arabidopsis ADP-ribose/NADH pyrophosphohydrolase, AtNUDX7, is involved in the response to oxidative stress. Plant Physiol 2009, 151(2):741-754

27. Durrant WE, Wang S, Dong X: Arabidopsis SNI1 and RAD51D regulate both gene transcription and DNA recombination during the defense response. PNAS 2007, 104(17):4223-4227.

28. Yang S, Perna NT, Cooksey DA, Okinaka Y, Lindow SE, Ibekwe AM, Keen NT, Yang $\mathrm{CH}$ : Genome-wide identification of plant-upregulated genes of Erwinia chrysanthemi 3937 using a GFP-based IVET leaf array. Mol Plant Microbe Interact 2004, 17(9):999-1008.

29. Pogson BJ, Albrecht V: Genetic dissection of chloroplast biogenesis and development: an overview. Plant Physiol 2011, 155(4):1545-1551.

30. Geu-Flores F, Moldrup ME, Bottcher C, Olsen CE, Scheel D, Halkier BA: Cytosolic gamma-glutamyl peptidases process glutathione conjugates in the biosynthesis of glucosinolates and camalexin in Arabidopsis. Plant Cell 2011, 23(6):2456-2469.

31. Storozhenko S, Belles-Boix E, Babiychuk E, Herouart D, Davey MW, Slooten L, Van Montagu M, Inze D, Kushnir S: Gamma-glutamyl transpeptidase in transgenic tobacco plants : cellular localization, processing, and biochemical properties. Plant Physio/ 2002, 128(3):1109-1119.

32. Ball L, Accotto GP, Bechtold U, Creissen G, Funck D, Jimenez A, Kular B, Leyland N, Mejia-Carranza J, Reynolds H, Karpinski S, Mullineaux PM: Evidence for a direct link between glutathione biosynthesis and stress defense gene expression in Arabidopsis. Plant Cell 2004, 16(9):2448-2462.

33. Molinier J, Stamm M, Hohn B: SNM-dependent recombinational repair of oxidatively induced DNA damage in Arabidopsis thaliana. EMBO Rep 2004, 5(10):994-999.

34. Young SA, Guo A, Guikema JA, White FF, Leach JE: Rice cationic peroxidase accumulates in xylem vessels during incompatible interactions with Xanthomonas oryzae pv oryzae. Plant Physiol 1995, 107(4):1333-1341.

35. Almagro L, Gomez Ros LV, Belchi-Navarro S, Bru R, Ros Barcelo A, Pedreno MA: Class III peroxidases in plant defence reactions. J Exp Bot 2009, 60(2):377-390.

36. Gulsen O, Eickhoff T, Heng-Moss T, Shearman R, Baxendale F, Sarath G, Lee $D$ : Characterization of peroxidase changes in resistant and susceptible warm-season turfgrasses challenged by Blissus occiduus. Arthropod-Plant Interact 2010, 4:45-55.
37. Heng-Moss T, Macedo T, Franzen L, Baxendale F, Higley L, Sarath G: Physiological responses of resistant and susceptible buffalograsses to Blissus occiduus (Hemiptera: Blissidae) feeding. Plant Resist 2006, 99(1):222-228.

38. Heng-Moss T, Sarath G, Baxendale F, Novak D, Bose S, Ni X, Quisenberry S: Characterization of oxidative enzyme changes in buffalograsses challenged by Blissus occiduus. Plant Resist 2004, 97(3):1086-1095.

39. Amundsen K, Rotter D, Li H, Messing J, Jung G, Belanger F, Warnke S: Miniature inverted-repeat transposable element identification and genetic marker development in Agrostis. Crop Sci 2011, 51:854-861.

40. Kumar S, Blaxter ML: Comparing de novo assemblers for 454 transcriptome data. BMC Genomics 2010, 11:571.

41. Li W, Godzik A: Cd-hit: a fast program for clustering and comparing large sets of protein or nucleotide sequences. Bioinformatics 2006, 22(13):1658-1659.

42. Lassmann T, Hayashizaki Y, Daub CO: TagDust-a program to eliminate artifacts from next generation sequencing data. Bioinformatics 2009, 25(21):2839-2840.

43. Schulz MH, Zerbrino DR, Vingron M, Birney E: Oases: robust de novo RNAseq assembly across the dynamic range of expression levels. Bioinformatics 2012, 28(8):1086-1092.

44. Surget-Groba Y, Montoya-Burgos Jl: Optimization of de novo transcriptome assembly from next-generation sequencing data. Genome Res 2010, 20(10):1432-1440.

45. Min XJ, Butler G, Storms R, Tsang A: OrfPredictor: predicting proteincoding regions in EST-derived sequences. Nucleic Acids Res 2005, 33(Web Server Issue):W677-W680

46. Conesa A, Gotz S, Garcia-Gomez JM, Terol J, Robies M: Blast2GO: a universal tool for annotation, visualization and analysis in functional genomics research. Bioinformatics 2005, 21(18):3674-3676.

47. Langmead B, Trapnell C, Pop M, Salzberg SL: Ultrafast and memoryefficient alignment of short DNA sequences to the human genome. Genome Biol 2009, 10(3):R25.

48. Anders S, Huber W: Differential expression analysis for sequence count data. Genome Biol 2010, 11(10):R106.

doi:10.1186/1471-2164-14-613

Cite this article as: Wachholtz et al.: Transcriptome analysis of two buffalograss cultivars. BMC Genomics 2013 14:613.

\section{Submit your next manuscript to BioMed Central and take full advantage of:}

- Convenient online submission

- Thorough peer review

- No space constraints or color figure charges

- Immediate publication on acceptance

- Inclusion in PubMed, CAS, Scopus and Google Scholar

- Research which is freely available for redistribution 